MYKOL ROMERIO
UNIVERITEIAS

\title{
THE PERSPECTIVE OF LONG-TERM ENERGY SUPPLY CONTRACTS IN THE CONTEXT OF EUROPEAN UNION COMPETITION LAW
}

\author{
Laura Rimšaitè \\ Mykolas Romeris University, Faculty of Law \\ Business Law Department \\ Ateities 20, LT-08303 Vilnius, Lithuania \\ Telephone: (+370 5) 2714633 \\ E-mail: rimsaitel@gmail.com
}

Received on 6 June, 2013; accepted on 28 July, 2013

doi:10.13165/SMS-13-5-3-12

\begin{abstract}
This article analyses long-term energy contracts in relation with third-party access right to energy transmission and distribution system. Long-term energy supply contracts remain quite controversial: while enhancing the need to create competitive common energy market and to increase diversification of energy sources, the obligation to supply energy sources is contracted for a long time period with the appropriate contracted price. These contractual obligations are not reviewed or adjusted according to changing market conditions. A problem occurs because long-term energy contracts limit the possibility for new market participants to enter and compete with the existing ones. The transmission system owners often abuse their right to refuse grant third-party access using an argument of long-term energy supply contracts with take-or-pay obligations. There is a doubt if the capacity reservation mechanisms, takeor-pay obligations and other limitations dealt in long-term contracts are in line with EU competition law requirements. However, long-term contracts provide stability of energy supply and also economic benefit to the consumer. The article analyzes long-term energy supply contracts perspective in the light of European Union competitive internal energy market.
\end{abstract}

Keywords: Long-term energy supply contracts, abuse of dominant position, take-or-pay obligation, third-party access, Third energy package, transmission network, European Union internal energy market. 


\section{Introduction}

Problems in energy market came to the outset when vertically integrated energy utilities exercised their dominant power in the market. Most experts agree that the energy market remains concentrated and dependant on dominant energy supplier. The European Union (hereinafter - the EU) adopted three energy packages ${ }^{1}$ which reflect ex ante regulation in order to create competitive common energy market and also to provide balance between security of energy supply ensuring third-party access to the transmission system ${ }^{2}$. However, undertakings may refuse to grant access if certain conditions are met, but long-term energy supply contracts with take-or-pay obligations put preconditions to abuse this right. According to the Directive, take-or-pay obligations ${ }^{3}$ may cause serious financial and economical difficulties to the undertaking which is carrying out public service obligations.

Long-term contracts relation with competition law has not been widely studied by the academic scholars. Hedge and Fjeldstad ${ }^{4}$ analysed several aspects of longterm natural gas contracts. Economic analysis of energy supply contracts was given by Neumann and Hirschausen ${ }^{5}$. F. Leveque ${ }^{6}$ made valuable insights into antitrust enforcement in the energy market. However, there is still a lack of comprehensive legal research including intercourse between energy sector regulation requirements and competition law enforcement in the light of the EU internal energy market.

The purpose of the research is to analyse long-term energy supply contracts in the perspective of common energy market as well as to evaluate the possible limitations, arising from contractual clauses, and correspondence with EU competition law.

The object of the research is the ratio of long-term supply contracts with the EU energy market liberalization mechanisms and competition law.

1 The first energy law package includes: Gas Directive 98/30/EC, Electricity Directive 96/92/EC. The second package includes: Gas Directive 2003/55/EC, Electricity Directive 2003/54/EC. The third energy package includes: Electricity Directive 2009/72/EC, Gas Directive 2009/73/EC, as well as three regulations: On conditions for access to the natural gas transmission networks (EC) No 715/2009; On conditions for access to the network for cross-border exchanges in electricity (EC) No 714/2009; Establishing an Agency for the Cooperation of Energy Regulators ACER (EC) No 713/2009.

2 Directives 2009/73/EC and 2009/72/EC explain transmission activities as a natural gas / electricity transportation via high-pressure piping / high voltage electrical network other than an upstream pipeline network and high-pressure pipelines primarily used in the local distribution of the natural gas in order to introduce them to consumers / distributors, with the exception of supply.

3 Take-or-pay obligation means that in the contract between the buyer and the seller there is set an appropriate amount of energy sources, which will be taken for the contractually agreed price, regardless of whether the physical quantity is served, the buyer pays the seller a negotiated price.

4 Hedge, K. and Fjeldstad, E. The Future of European Long-term Natural Gas Contracts. Oslo, 2010.

5 Neumann, A. and Hirschhausen, Ch. Less Long-Term Gas to Europe? A Quantitative Analysis of European Long-Term Gas Supply Contracts. Zeitschrift fur Energiewirtschaft. 2004, 28(3): 175-182.

6 Leveque, F. Antitrust Enforcement in the Electricity and Gas Industries: Problems and Solutions for the EU. The Electricity Journal. 2006, 19(5): 27-34. 
The research methods include the systematic analysis method ${ }^{7}$ used in an integrated way through the competition law analysis of the Court of Justice of the European Union (hereinafter - the CJEU) practice, the European Commission (hereinafter - the Commission) decisions and practical aspects of the application analysis to look at the energy sector, long-term energy contracts and to identify the most common problems. The application of this method is important to find an alternative as well as solving problems and understanding the unknown options by examining them. Comparative historical method ${ }^{8}$ helps to collate the relevant phenomena in different historical stages of development and fully discloses the origins of the problem and identifies the cause.

\section{Long-Term Energy Supply Contracts Origins and Contradictions}

Long-term energy supply contracts are awarded to ensure major projects financing and they are also quite attractive for contracting parties - usually the seller - due to durations that range from fifteen to thirty years, since this period is optimal for incurred investment return. Assessing long-term energy infrastructure projects and particularly large initial investment and the subsequent period of lower operating costs for project developing companies, such contracts ensure stable investment returns through investment payback period, thus reducing the risk incurred by the energy project implementing company ${ }^{9}$. Retrospectively, in Europe long-term contracts with Russia (former Soviet Union) were contracted since 1970 to ensure that major energy infrastructure projects meet consumer demand for natural gas. The contracts were based on the so-called "Groningen model", which was widely applied in the Netherlands since 1962, when the return on investments was made for the whole period, while natural gas prices were determined in conjunction with other fuel price index. ${ }^{10}$ Changing situation in the natural gas markets as well as the development of technologies fostered to conclude long-term contracts for shorter periods. It is important to mention that the infrastructure investment needs gradually less money because the development of new projects mostly requires the improvements of existing system, also the technology price decreases. Competitiveness to some extent is enhanced by emerging spot market and energy trade exchanges. The development of alternative natural gas sources (Shale gas exploration processes in Poland, Hungary and Germany) reduce the need to ensure security only one way.

7 Tidikis, R. Socialiniu mokslų tyrimų metodologija. [Social Sciences Research Methodology]. Lietuvos Teisès universitetas, 2003.

$8 \quad$ Ibid., p. 30.

9 Smith, E.; Dzienkowski, J. et al. International Petroleum Transactions. Rocky Mountain Mineral Law Foundation, 2010.

10 Konoplyanik, A. Gas Transit in Eurasia: Transit Issues between Russia and the European Union and the Role of the Energy Charter. Journal of Energy and Natural Resources Law. 2009 (27/3): 445-483. 
Long-term energy supply contracts are quite controversial because of its benefits to market operators and potential conflicts to the competition law. On one hand, it ensures the security of energy supply as well as provides ability for suppliers to plan long-term investments that require significant financial resources in the energy sector. The main positive feature of the long-term energy supply contracts is the opportunity to buy long-term energy resource at a predetermined price formula, which at least should be legally protected from the larger fluctuations in the price and thus contribute to the security of energy supply. For this reason, long-term supply contracts to some extent are assessed as lower risk contracts. It should be noted that such contracts provide risksharing mechanism between the buyer and the seller, which is mandatory according to high initial project investments. The long run investment return period preconditions price, energy demand fluctuations in the market and also certain political changes may result into modifications in the legal framework. Therefore, it is important to assess this risk and to provide certain "safeguards". These contracts partially prevent the market from major price hikes and ensure a stable fixed price quotation. However, they create a situation, where the buyer and the seller are associated with long-term obligations ${ }^{11}$. The problem arises due to the fact that negotiations on the long-term supply contracts start two or three years prior to the transaction and the contracting parties after evaluation of future energy demand in the market for the long run shall provide the quantity of energy, which is planned to be acquired. Energy demand in the market may change and, therefore, a balanced amount of energy can actually render superfluous, but with the takeor-pay obligation contracting parties do not adjust the agreed quantities to the changing market situation. On the other hand, the long-term supply contracts may be harmful, especially if they are awarded by dominant undertakings which make difficulties for new operators to enter the market ${ }^{12}$. After a certain period of time, fixed price in the long-term supply contracts often does not reflect the changing market trends, thus creates preconditions for market foreclosure. The Commission conducted an inquiry into the energy sector in 2007 and posted a Communication ${ }^{13}$, where it was stated that the energy market is still at a high level concentration, and poorly implemented unbundling requirement to vertically integrated companies still existed ${ }^{14}$. In this Communication, the Commission also stressed the importance to evaluate the vertical tying of markets by long-term contracts, since it is a risk that a dominant undertaking creates market distortions and may breach competition law implications. After a sector inquiry the Commission did not take any active measures for price regulation, since it would not affect market concentration or diminish market liquidity reasons, but only deal with the

11 Neumann, A.; Hirschhausen, Ch. supra note 5.

12 Leveque, F. supra note 6.

13 Communication from the Commission. Inquiry pursuant to Article 17 of Regulation (EC) No 1/2003 into the European gas and electricity sectors (Final Report) COM (2006) 851.

14 Vertically integrated company pursuant to Directives 2009/73/EC and 2009/73/EC is the enterprise or group of undertakings where the same person or the same persons are entitled, directly or indirectly, to exercise control and where the undertaking or group of undertakings perform at least one of the transmission, distribution, LNG or storage and at least one of natural gas (in electricity) production and supply functions. 
consequences $^{15}$. Subsequent Commission Communication ${ }^{16}$ states that the wholesale gas markets are still at a high level concentration, when the number of wholesalers has captured a 90\% market share; the ownership unbundling vertically integrated utilities remains not implemented and also there is some discrepancy between de facto and de jure network capacity reservations. This means that the contracts are dealt with the network reservations, but physically the capacity remains not exhausted.

According to the Commission, long-term energy supply contracts should not create market leverage or hamper competition between operators. Monopolistic power companies with long-term contracts with take-or-pay obligations should not prevent competition in the market ${ }^{17}$. It is worth noting a few clauses used in long-term supply contracts: the destination clause, the oil price indexation and the take-or-pay obligation.

According to competition law, the destination clause is a kind of territorial restriction, where a purchaser of natural gas is prohibited to resell energy to other entities in a single country. Major producing companies sell products to distribution companies, but not directly to consumers. Sales are limited to the area, where supply companies have networks, and are not allowed to resell energy to other operators in the market in another area ${ }^{18}$. In this way, a condition prohibiting suppliers to resale purchased resources in another area, allowing the same product sold in different areas in the market price to different subjects, creates a market foreclosure effect. According to competition law, it is considered to be an exclusive purchasing, which is regarded as one of the forms of abuse of a dominant position. Some authors distinguish alternatives applicable to destination clause - the profit-sharing mechanism, under which the supplier undertakes to share the profits with the manufacturer for the resale of purchased products in another area. Such a profit-sharing mechanism with the supplier can be applied in cases, where production is used in purposes, which cause breach of the use restriction settled in the long-term contract ${ }^{19}$. An example is a situation, where electricity or heat energy producer in the production process using natural gas, which is purchased from a supplier, may not be used for other purposes, just as a fuel for electricity or thermal energy; the producer cannot sell the gas directly to the consumer. Such profit-sharing mechanisms, though usually as an alternative to territorial restrictions, create similar barriers to competition and may be likened to the territorial trade barriers and also breach the EU competition law.

Other long-term energy supply contracts condition is the oil price indexation. Oil price changes at the international market affects gas and electricity contractual prices, as the price of oil markets is used as a base price under long-term gas and electricity

15 Energy sector competition inquiry - preliminary report. MEMO/06/78.

16 Communication from the Commission to the Council and the European Parliament. Report on Progress in Creating the Internal Gas and Electricity Market COM (2010) 84.

17 Creti, A. and Villeneuve, B. Long-term Contracts and Take-or-Pay Clauses in Natural Gas Market. Energy Studies Review. 2004 (13, 1): 87.

18 Talus, K. Long-term Natural Gas Contracts and Antitrust Law in the European Union and the United States. Journal of World Energy Law and Business. 2011 (4, 3): 260-315. 
supply contracts. Oil, gas and electricity prices apply to a hypothetical possibility of a consumer to select the type of fuel ${ }^{20}$. Recently, after a significant increase of oil prices, this pricing model has reflected considerable discussion, as gas or electricity prices linking to the price of oil potentially creates some obstacles to diversify energy sources and thus potentially reduce the level of energy security supply. It should be mentioned that because of the increase in liquefied natural gas capacity and the development of unconventional gas (shale), gas trading hubs results into significantly lower prices ${ }^{21}$ than the expected long-term contracts with the oil index-linked prices.

The take-or-pay obligation provides that long-term energy supply contracts are negotiated with a certain minimum amount of supplies, for which the buyer is obliged to pay a pre-negotiated price, regardless whether such amount is needed. It should be noted that this condition ensures a supply of energy stability and security, while also implies a certain risk-sharing mechanism ${ }^{22}$. On the other hand, such condition without free content preview options can be seen as a form of abuse of a dominant position. Accordingly, when the contracts with take-or-pay obligations also set the territorial and use restrictions, entities become bound by a long-term bilateral monopoly contract.

In conclusion, it should be noted that the long-term energy supply contracts contribute to the security of energy supply, create stability and reduce the risk of supply interruption, while promoting investment, especially when the project is risky. These contracts minimize the potential uncertainty of energy supply in the market. Also, the investment can be planned for longer periods ${ }^{23}$. On the other hand, the negative side of contracts should not be overshadowed, as they create a foreclosure effect, increase market concentration and reduce ex ante competition, since price changes in the markets do not reflect changes in the contracted price. Third energy package provides exemption for the third-party access to the network. Firstly, when the transmission network owners have entered into the long-term supply contracts with the take-orpay obligations and the reduction in the amount of resources incur significant losses, owners are allowed to refuse to grant the third-party access to the network. Secondly, the refusal to grant the third-party access is available because of insufficient capacity or the company's obligation to provide public service.

\subsection{Lithuania's natural gas market overview: long-term supply contracts status quo and perspective}

Lithuania is currently dependant on a sole external natural gas supplier from Russia. Such position of the external supplier is due to the fact that Lithuania's natural

20 Putting a Price on Energy: International Pricing Mechanisms for Oil and Gas. ECT secretariat, 2007. See also Stern, J. Is There a Rationale for the Continuing Link to Oil Product Prices in Continental European Long Term Contracts? OIES.6. 2007.

21 COM (2006) 851. supra note 13.

22 Hedge, K.; Fjeldstad, E. supra note 4.

23 Holt, D. The Long and Short of It: The Impact of Long-term Contracts as a Commercial Tool. Oxera. Agenda. 2007. 
gas system lacks interconnections with Europe to secure the so-called infrastructure standard (N-1). ${ }^{24}$ Also, there are no current measures to limit natural gas pricing, which creates overall price growth of Lithuania's natural gas, electricity and heat. It should be noted that the Commission has launched an investigation of competition law infringement against the Russian company OAO "Gazprom", related to the abuse of a dominant position. As noted in the Commission's report, the investigation carried out OAO "Gazprom's" actions, which affected the liberalization process and resulted into an unfair pricing. ${ }^{25}$ In this case, worth mentioning is the situation in the Lithuanian gas market, since the company AB "Lietuvos dujos" has entered into a long-term gas supply contract with OAO “Gazprom” until 2014. Lithuania issued a complaint against OAO "Gazprom" for LTL 5 billion overpayment for the supply of gas. In 2004, comprising AB "Lietuvos dujos" privatization contract, "Gazprom" obligated to supply natural gas to Lithuania due to gas price formula negotiated in the contract. However, considering the period between 2004 and 2012, gas price increased according to formula changes made in violation of the privatization contract. In 2012, July Arbitration Tribunal rejected "Gazprom's" claims for damages ${ }^{26}$.

Law on Liquefied Natural Gas terminal (hereinafter - the LNG terminal) ${ }^{27}$ created legal prerequisites for the alternative natural gas supplies to secure the implementation of the so-called N-1 security standard, as well as minimize dependence on external natural gas supplier. It is worth noting that Lithuania lacks negotiating leverage in lower prices because it takes only 0.6 percent of a total OAO “Gazprom" Group's gas production volume. For comparison, Latvia, with its gas storage Incukalns, and Estonia, using shale gas, find themselves in a better negotiating position on gas prices with an external natural gas supplier. Examining the long-term natural gas supply contracts, attention should be drawn to the price calculation, when OAO Gazprom supplies natural gas with the price linked to the oil price index. This pricing formula prevailed in 1980-2005 in Europe, when oil prices were relatively stable and satisfied natural gas consumers' demand. However, when oil prices reached unprecedented heights, they became non competitive. Possibility to use alternative sources and formation of spot

24 European Parliament and Council Regulation (EU) No. 994/2010 on the gas supply security measures and repealing Council Directive 2004/67/EC [2010] OJ 2010 L 295/1. Article 6 requires Member States no later than 3 December, 2014 to ensure the natural gas infrastructure standard (N-1), must be satisfied with the overall demand for natural gas in the Territory, in case of the disruption of the single largest gas infrastructure of exceptionally high gas demand on the day, with a statistical probability of occurring once every 20 years.

25 Commission Opens Proceedings against Gazprom. 4 September, 2012, Commission Press Release, $\mathrm{IP} / 12 / 937$.

26 OAO Gazprom v. Republic of Lithuania. Final Award. 31 July, 2012. Arbitration No.: v. (125/2011) [interactive]. [assessed on 03-06-2013]. <http://arbitrations.ru/files/articles/uploaded/Gazprom_v_ Lithuania_Final_Award_SCC.pdf $>$.

27 Law on Liquefied Natural Gas Terminal of the Republic of Lithuania. Official Gazette. 2012, No. 68-3466. On 14 November, 2012 Parliamentary Group of the Republic of Lithuania asked the Constitutional Court to examine whether certain provisions of the Act and its implementing provisions of the decree of the Government of the Republic of Lithuania is not in conflict with the Constitution. 2012.12.12 Constitutional Court returned part of the application to the applicant. File no.: 23/2012. 
market preconditioned possible price decreases. The spot market operates in the supplydemand principle, when the price is fixed in the short term, taking into account the prevailing market prices, but also due to the excess volume of natural gas in the market, they can be sold in a competitive price without binding long-term commitments. On the other hand, the security of energy supply is not justified, since the need remains to ensure an uninterrupted supply. Formation of gas exchanges noticeably declines prices of natural gas, compared with the prices to the long-term contracts. After the development of natural gas exchanges in Great Britain, Holland, the USA or the longterm supply contracts, linking prices not to the oil price index, but to the gas exchange indexes, the prices fall accordingly.

It should be noted that the LNG terminal contracts will be of mid-term (for about 5 years) as well as short-term duration. This means that about $20-25 \%$ of all contracts will be mid-term gas supply contracts, the rest will be short-term supply contracts, which, as it has been already mentioned, have certain advantages on the spot market. Such contracts will be subject to diversification to balance stability, while maintaining the mid-term supply contracts ensure competitive prices for consumers, buying natural gas in the spot markets using the demand-supply principles.

\subsection{Electricity market situation and supply contracts in Lithuania}

Electricity sector has undergone significant changes since 2010. Until then, a major part of the contracts were of long-term duration as well as all the production, transmission and supply activities were concentrated in the vertically integrated company AB "Lietuvos energija". After Ignalina nuclear power plant closure, Lithuania became the importing country from the exporting electricity state. More than half consumed electricity is imported from neighbouring countries, mainly from Russia. Lithuania is also dependent on electricity produced using natural gas, which is imported from a single external supplier. The electricity transmission network is not connected to the continental European and Nordic networks. These connections are important to take advantage of the EU's common energy market. Due to liberalisation requirements, AB "Lietuvos energija" was unbundled by separating transmission, supply and generation activities. Baltic Energy Market Interconnection Plan (BEMIP) encouraged to build a competitive internal energy market in the region. Also, since 2010, when power exchange was launched, free electricity market has been developing in the country. It should be noted that in the current market there are independent suppliers who gradually take over customers from the distribution company LESTO. Attention is drawn to the fact that since 18 June, 2012 Lithuania has become a member of Nord Pool Spot.

The electricity produced by the $\mathrm{AB}$ "Lietuvos energija" is sold to public and independent suppliers as well as exported and traded in Lithuanian power exchange. Market liberalization process takes place in stages, where legal entities will have to choose independent electricity suppliers at different time, depending on the subject allowed capacity ${ }^{28}$.

28 Law on Electricity of Republic of Lithuania. Official Gazette. 2012, No. 17 752. Article 43 found that since 1 January, 2013 public supplier must enter into contracts and to supply electricity to the public electricity 
Since the beginning of 2010, for all users except households electricity price is calculated according to the new pricing, which clearly separates electricity cost from the transmission rates. Electricity transmission price is the same, regardless from whom a consumer is buying it, a public or an independent supplier. Each year, the service provider confirms the price, and the National Prices and Energy Control Commission publishes it. In conclusion, Lithuania has enacted the necessary legislation in the electricity sector and is implementing market liberalization mechanisms under the requirements of the Third Energy Package.

\section{Long-Term Energy Supply Contracts - the Reason to Refuse to Grant a Third-Party Access?}

European wholesale gas market is at a high level market concentration; the major part of natural gas is imported from several vendors under specific conditions. Almost $40 \%$ of natural gas is imported from Russia and Algeria under long-term contracts, which increases market concentration and reduces conditions for new entrants. According to Directive 2009/72/EC and Directive 2009/73EC, businesses are entitled to refuse to grant a third-party access to the pipeline because of insufficient capacities or the existing take-or-pay obligations, presupposing serious financial and economic difficulties to the companies, which are implied by public service obligations. Refusal to grant access may be treated as a refusal to supply because the transmission network owner failing to allow another entity to use existing infrastructure restricts the latter to diversify resources and choose their supplier. Often, such a refusal to supply creates market foreclosure, when access is denied to the network connecting a number of countries, thus limiting the ability to supply alternative resources and maintaining the entity's dominant position in the market.

The refusal to supply as a form of abuse of a dominant position was first named in 1972 Commercial Solvents ${ }^{29}$ case, which held that refusal to cooperate may be considered as breach of Article 102 of the Treaty on the functioning of the European Union (hereinafter - TFEU). Legal doctrine explains that the dominant company refusing to cooperate with a competitor in the downstream market ${ }^{30}$ may infringe competition law, which means that all competition would be eliminated from the market. The Commercial Solvents case doctrine is usually applied to the dominant position in the market for vertically integrated companies, which supply essential resources in the downstream market $^{31}$. In 1983, the Commission developed the refusal to the supply concept in the

price for the entire license issued to the territory specified in the household customers who have not chosen an independent electricity supplier.

29 Commercial Solvents [1972] OL L 299/51.

30 Downstream market contracts are understood as "secondary market" contracts in which energy from the mining company or an external supplier acquired entities are sold to downstream transmission activities by traders, using bilateral long-term contracts or spot markets, so these energy resources are made available to consumers.

31 Wish, R. Competition Law. 6 edition. Oxford, 2008. 
$\mathrm{XIII}^{32}$ report, which explained that objectively the refusal to supply is unjustified, when an entity supplies goods on the condition that it controls the processing of goods or sale $^{33}$. The Commission submits to the interpretation that the refusal to supply is seen as the refusal to supply products to existing or new customers, as well as the refusal to license intellectual property rights, including cases where the license is necessary to provide information about the interface, or the refusal to allow use of essential equipment or network. As noted in the Commission's Communication, unreasonable obligation to supply may particularly breach entity's rights, and the Commission each time has to consider carefully the extent of its powers for the application of competition law in the area. Attention is drawn to the fact that the unreasonable obligation to supply may cause damage to the entity's property rights. The right to choose business partners is widely recognized in Member States even as a constitutional principle ${ }^{34}$.

The obligation to supply may have a negative effect on investment as the dominant entity, avoiding situations where their competitors are obliged to provide access to the network. Also, they may refuse to invest in the infrastructure, thus, it may not only have a negative effect on the business, but also limit consumer's right to get energy resources at competitive prices. A possible and lucrative situation, where the new entity seeks to enter the market, does not invest in equity of infrastructure development, but seeks to take an advantage of the work already done by the dominant market operator in the number of investments for the infrastructure development. In the long run, the dominant operator's refusal to grant access has a positive effect because it promotes competition, when the operator seeks other alternatives to enter the market, thus creates a benefit to consumers, but in the short term, the obligation to grant access to the network creates the situation, where the entity will not be interested to invest in the energy infrastructure, but will desire to take the advantage of the existing infrastructure.

\section{Overview of Long-Term Energy Supply Contracts Case Law}

Long-term supply contracts do not breach Article 102 of the TFEU provisions, but in each case the Commission investigates whether the contracts contain certain conditions that violate Article 102 of the TFEU ${ }^{35}$ and every time the Commission evaluates the long-term contracts taking into account the long-term supply contract duration, company's position in the market (whether it has a dominant position;

32 XIII $^{\text {th }}$ Report on Competition Policy (1983).

33 The following cases are related and examined more detailed refusal to supply in downstream markets: Case C-22/78 Hugin Kassaregister AB \& Hugin Cash Registers Ltd v. Commission [1979] ECR 1869; Joined cases C-241/91 and C-242/91 Radio Telefis Eireann (RTE) and Independent Television Publications Ltd (ITP) v. Commission (Magill) [1995] ECR I-00743; Case C-333/94 P Tetra Pak International SA v. Commission (Tetra Pak II) [1996] ECR I-5951; Case No IV/30.979 and 31.394 Decca Navigator System [1989] OJ L 43/27.

34 Opinion of Advocate General Jacobs in Case C-7/97 Oscar Bronner GmbH \& Co. KG v. Mediaprint Zeitungs- und Zeitschriftenverlag GmbH \& Co. KG and Others [1998] ECR I-07791, paras. 56-58.

35 Commission (EC), Antitrust: Commission Increaces Competition in the Belgian Gas Market - Frequently Asked Questions. MEMO 07/407. 
assesses its impact on the market) and the uniqueness of the contractual relationship, identifies the share of the market held by the company, and, finally, the effectiveness of the supply contracts. According to the case law, the company holding a dominant position in the market acquires a special responsibility to the extent seen in each situation $^{36}$. The assessment of dominance is based on the following factors: pressure on supply of competitors and their market position, exposure to the possibility that future competitors expand or possible entrance opportunities of new competitors, pressure from the company's customer bargaining power. The Commission believes that an action on Article 102 of the TFEU can be taken only after a careful evaluation of all the circumstances, because a company may be obliged to supply ${ }^{37}$. The refusal to supply also includes the company's refusal to grant access right to the network ${ }^{38}$. When the dominant companies may be obliged to supply against their will, on average, they may refuse to invest or decide to invest less in their activity. Situations may arise, where the competitors use in vain the undertakings incurred investment for infrastructure networks improvement, avoiding potential obligations by investing in the network development. According to the Commission, the refusal to grant the right of access may lead to negative consequences: the refusal relates to a product that is objectively necessary for the company to compete in the market, the refusal diminishes effective competition in the market, and this refusal potentially causes harm to consumers.

Distrigaz case formed a long-term energy supply contracts limitation model ${ }^{39}$. In this case, the Commission reached a settlement with Distrigaz to agree on the new contracts with customers for duration up to 2 years and the contracts with industrial users for up to 5 years. It also provides a repealing condition, which means that if Distrigaz total share value falls more than $40 \%$ or the nearest competitor's share rises more than $20 \%$, this entity will not be subject to such requirements ${ }^{40}$. From 2007 until 2010 , Distrigaz committed to ensure that every year $65 \%$ to $70 \%$ of contracted volumes will return to the market, thus allowing other suppliers to make competing bids ${ }^{41}$.

In $E D F$ case, the Commission also reached a settlement with the company, where the long-term contract with new customers would not exceed 5 years. The entity also obliged not to impose resale restrictions. From 1 January, 2010 until 31 December,

36 Case C-322/81 Nederlandsche Banden Industrie (Michelin I) v. Commission (1983), ECR 3461, para. 57; Case T-83/91 Tetra Pak v. Commission (Tetra Pak II) (1993), ECR II-755, para. 114; Case T-111/96 ITT Promedia v. Commission (1998), ECR II-2937, para. 139; Case T-228/97 Irish Sugar v. Commission (1999), ECR II-2969, para. 112 and Case T-203/01 Michelin v. Commission (Michelin II) (2003), ECR. II-4071, para. 97.

37 Joined cases C-241/91 P and C-242/91 Radio Telefis Eireann (RTE) and Independent Television Publications Ltd (ITP) v. Commission (Magill) (1995), ECR I-743, para. 50; Case C-418/01 IMS Health v. NDC Health (2004), ECR I-5039, para. 35; Case T-201/04 Microsoft v. Commission (2007), ECR II-3601, paras. 319, 330-332 and 336.

38 Commission Decision No 94/19/EB in Case IV/34.689 Sea Containers v. Stena Sealink - Interim Measures (OL L 15, 19941 18, p. 8) and Commission Decision No 92/213/EEB in Case IV/33.544 British Midland v. Aer Lingus (OL L 96, 19924 10, p. 34).

39 Distrigaz (Case COMP/37.966). Commission Decision of 11 October, 2007 [2007] OJ C9/5.

40 Ibid.

41 Ibid. 
2019 the EDF will ensure that $60 \%$ to $65 \%$ of the contracted volume will return to the market every year ${ }^{42}$. Harm of the long-term supply contracts occurs with an obligation to major energy consumers not to change a supplier for a longer period of time. In this way, other competitors are losing their right to facility access for a specified period. The problem arises when new entrants cannot enter the market and compete equally with the existing operators, as well as the smaller players face the potential risk of losing existing customers.

In $R W E^{43}$ and $E N I$ cases, the Commission held that the denial to grant thirdparty access to the facility is harmful to consumers and competitors, when network access is necessary to act in the neighbouring markets, the refusal to grant access may abolish market competition in the neighbouring market. When network companies are vertically integrated utilities, they are interested to favour their own affiliates in the market, thus distorting the competition. The refusal to grant access to the market is often motivated by a number of reasons: lack of technical networks capacity, also the long-term supply contracts with producers. Restrictions denying access to the network are often considered justified when resulting from the company's incurred investment costs in the development of the network infrastructure and are justified because of the payback period. RWE company's refusal to provide access was motivated by capacity hoarding, inadequate capacity structure and the initial supply volume reservations. The Commission held that such network abuse was concerted by keeping capacity for its own supply business, especially for bottle necks. Secondly, the RWE imposed high transportation tariffs on the downstream, which prevented competitors from competing effectively ${ }^{44}$. In the $E N I^{45}$ case, the company refused to grant capacity on transit pipelines from Germany and Austria and motivated the refusal to grant access rights with capacity reservation and already made investments into the infrastructure development. However, the Commission objected to the strategic underinvestment argument.

Worth mentioning is the German company E.ON Ruhrgas case. The national regulatory authority FCO (Federal Cartel Office) obligated the company to terminate the long-term contracts until 30 September, $2006^{46}$. The new long-term supply contracts covering $80 \%$ to $100 \%$ distributor's requirements shall not exceed 2 years period and the contracts covering $50 \%$ to $80 \%$ will not exceed 4 years. The E.ON appealed against the authority's decision. The appellate court in this case agreed with the national regulator's position that certain clauses were not in compliance with national law ${ }^{47}$. At the same

42 Commission (EC). Notice published pursuant to Article 27(4) of Council Regulation (EC) No 1/2003 in case COMP/B-1/39.386-Long- term contracts. France [2007] OJ C262/32.

43 RWE Gas Closure (Case COMP/39.402). Commission Decision of 18 March, 2009. [2009] OJ C 133/8.

44 Ibid.

45 ENI Foreclosure (Case COMP 39.315).

46 Federal Cartel Office (Bundeskartellamt), 13 January, 2006, Decision B 8 - 113/03, E.ON Ruhrgas [interactive]. [accessed on 25-05-2012]. $<$ http//www.bundeskartelamt.de $>$.

47 Court of Appeal Dusseldorf (Oberlandesgericht Dusseldorf), 20 June, 2006, VI-2 Kart 1/06 (V) - E.ON Ruhrgas [interactive]. [accessed on 25-05-2012]. <http://www.justiz.nrw.de>. 
time, the court recognized that in the absence of the third-party access, the market remains closed. Vertical agreements restrict the competition between the E.ON and other gas suppliers and between the E.ON and large distribution network companies, which act as suppliers in the market. Contrary to the FCO's decision, the court does not impose certain restrictions as a condition of $80 \%$ of purchases ${ }^{48}$. The E.ON makes several arguments to motivate clauses applied to this case. Firstly, the duration of the long-term contracts is questionable and should be similar to that used in the contracts with the take-or-pay obligations. In shorter agreements, the E.ON should assume all risk arising from the long-term contracts. It also argues that the restrictions can ensure low prices for a long period. The court did not justify the take-or-pay obligations in the long-term contracts with the need to ensure security of the supply in the market. The court also noted the decreased duration of the long-term contracts and in this case the company's argument to pay off incurred investment is rather doubtful.

It is worth noting that the long-term electricity supply contracts were limited to 15 years, considering that this period did not create preconditions for the abuse of the dominant position and the market foreclosure, as nuclear power investment payback period is about 30 years. The Commission considers that this period is sufficient in view of investments return and continuing on competitive conditions in the market along with other operators ${ }^{49}$. In Scottish Nuclear, Nuclear Energy Agreement cases, the Commission held that the contract was set with the take-or-pay obligations, where the electricity produced by the nuclear power plant was sold under the long-term 30 year contract and was awarded to the two supply companies. The Commission reiterated its decisions in subsequent $\operatorname{cases}^{50}$, stating that the nuclear power electricity supply longterm contracts should be no longer than 15 years. In those cases, the Commission found that the electricity supply contracts are awarded solely between the electricity producers and the monopolistic generation companies, and when they are awarded, the market remains closed for a long period. Another case, in which the Commission assessed the long-term electricity supply contracts, is REN / Turbogas ${ }^{51}$, when a compromise was reached on the pricing periods, when for the first fifteen years the generator set higher prices, and for the remaining period lower electricity sales prices were negotiated. It is worth noting that in the Commission's decision in ISAB Energy ${ }^{52}$ case, the twenty-year long-term contract has not been cancelled, but the Commission saved the reservation after fifteen years to check on the market functioning. The Commission's position on the nuclear power plants generated electricity supply contract is a compromise in a sense, that such contracts are necessary to ensure long-term security of the energy supply, and secure the massive investment return of nuclear energy infrastructure installation.

48 Court of Appeal Dusseldorf (Oberlandesgericht Dusseldorf), supra note 47.

49 (EEC) 91/329; Commission Decision of 30 April, 1991 relating to a proceeding under Article 85 of the EEC Treaty (IV/33.473 - Scottish Nuclear, Nuclear Energy Agreement).

50 Electricidade de Portugal/Pego Project (Notice pursuant to Article 19(3) of Regulation 17) [1993] OJ $\mathrm{C} 265 / 3$.

51 REN/Turbogas (Notice pursuant to Article 19(3) of Regulation 17) [1996] OJ C118/7.

52 ISAB Energy (Notice pursuant to Article 19(3) of Regulation 17) [1996] OJ C138/3. 


\section{Conclusions}

1. Limitations to use network are understood as one of the forms of abuse of a dominant position. Quite often, there are situations, where a dominant network company conducting energy transmission activities unreasonably refuses to grant network access for other operators. In this way, a vertically integrated company has a significant leverage and artificially creates barriers for other operators to enter the market and thus keeps the bulk of the supply market.

2. A Commission study on the mismatch of competition law settled respective obligations to natural gas companies with a dominant position in the market, limiting long-term supply contracts for the maximum term, including other requirements. The long-term contracts per se do not presuppose the breach of competition law, however, certain contractual clauses, such as the take-or-pay obligation, use restrictions and the destination clause, which are implemented by an undertaking, shows that holding a dominant position brings up market distortions, which leads to the foreclosure effect.

3 . The long-term energy supply contracts are an important factor to ensure the incurred energy infrastructure installation costs payback. In this way, relevant major energy infrastructure (gas, oil, nuclear energy) project funding stability is ensured. It would be useful to draw attention to the company's incurred costs to the infrastructure investment and mandatory investment return time. Therefore, in addition to the contracts duration, a periodic review of its terms and conditions and also more flexible price review options considering the changing market conditions, thus maintaining need for operators to continue receiving a negotiated amount of energy, should be included.

\section{References}

Case C-322/81 Nederlandsche Banden Industrie (Michelin I) v. Commission (1983), ECR I-3461.

Case C-418/01 IMS Health v. NDC Health (2004), ECR I-5039.

Case T-83/91 Tetra Pak v. Commission (Tetra Pak II) (1993), ECR II-755.

Case T-111/96 ITT Promedia v. Commission (1998), ECR II-2937.

Case T-203/01 Michelin v. Commission (Michelin II) (2003), ECR II-4071.

Case T-228/97 Irish Sugar v. Commission (1999), ECR II-2969.

Case T-201/04 Microsoft v. Commission (2007), ECR II-3601.

Commission (EC), Antitrust: Commission Increases Competition in the Belgian Gas Market. MEMO 07/407.
Commission Opens Proceedings against Gazprom. 4 September, 2012, Commission Press Release, IP/12/937.

Commission (EC). Notice published pursuant to Article 27(4) of Council Regulation ( EC) No 1/2003 in Case COMP/B-1/39.316-Gaz de France (gas market foreclosure). [2009] OJ C 156/14.

Commission (EC). Notice published pursuant to Article 27(4) of Council Regulation (EC) No $1 / 2003$ in case COMP/B-1/39.386 Longterm contracts. France [2007] OJ C262/32.

Communication from the Commission. Inquiry pursuant to Article 17 of Regulation (EC) No 1/2003 into the European gas and electricity sectors (Final Report). COM (2006) 851. 
Communication from the Commission to the Council and European Parliament. Report on progress in creating the internal gas and electricity market. COM (2010) 84.

Commission Decision of 26 February, 1992 92/213/EEB case IV/33.544 British Midland v. Aer Lingus (OL L 96, 19924 10, p. 34).

Commission Decision of 21 December, 1993 94/19/EB case IV/34.689 Sea Containers $v$. Stena Sealink - Interim Measures (OL L 15, 19941 18, p. 8).

Court of Appeal Dusseldorf (Oberlandesgericht Dusseldorf), 20 June, 2006, VI-2 Kart 1/06 (V) - E.ON Ruhrgas [interactive]. [accessed on 25-05-2012]. <http://www.justiz.nrw. de>.

Creti, A. and Villeneuve, B. Long-term Contracts and Take-or-Pay Clauses in Natural Gas Market. Energy Studies Review. $2004(13 / 1)$.

Directive 2009/72/EC of the European Parliament and of the European Council concerning common rules for the internal market in electricity, repealing Directive 2003/54/EC. [2009] OJ L 211/63.

Directive 2009/73/EC of the European Parliament and of the European Council concerning common rules for the internal market in natural gas and repealing Directive 2003/55/EC. [2009] OJ L 211/94.

Distrigaz (Case COMP/37.966). Commission Decision of 11 October, 2007 [2007] OJ C $9 / 5$.

EEC 91/329; Commission Decision of 30 April, 1991 relating to a proceeding under Article 85 of the EEC Treaty (IV/33.473 - Scottish Nuclear, Nuclear Energy Agreement).

Electricidade de Portugal/Pego Project (Notice pursuant to Article 19(3) of Regulation 17) [1993] OJ C265/3.

Energy sector competition inquiry preliminary report - frequently asked questions. MEMO/06/78.

ENI Foreclosure (Case COMP 39.315).

Federal Cartel Office (Bundeskartellamt), 13 January, 2006, Decision B 8 - 113/03, E.ON Ruhrgas [interactive]. [accessed on 25-052012]. <http//www.bundeskartelamt.de>.
Hedge, K. and Fjeldstad, E. The Future of European Long-term Natural Gas Contracts. Oslo, 2010.

Holt, D. The Long and Short of It: The Impact of Long-term Contracts as a Commercial Tool. Oxera. Agenda. 2007.

ISAB Energy (Notice pursuant to Article 19 (3) of Regulation 17) [1996] OJ C138/3.

Joined cases C-7 and C-7/73 Commercial Solvents v. Commission [1972] OL L 299/51.

Joined cases C-241/91 P and C-242/91 Radio Telefis Eireann (RTE) and Independent Television Publications Ltd (ITP) $v$. Commission (Magill) (1995), ECR I-743.

Konoplyanik, A. Gas Transit in Eurasia: Transit Issues between Russia and the European Union and the Role of the Energy Charter. Journal of Energy and Natural Resources Law. 2009 (27/3): 445-483.

Law on Electricity of the Republic of Lithuania. Official Gazete. 2012, No 17-752.

Law on Liquefied Natural Gas Terminal of the Republic of Lithuania. Official Gazette. 2012, No. 68-3466.

Leveque, F. Antitrust Enforcement in the Electricity and Gas Industries: Problems and Solutions for the EU. The Electricity Journal. 2006, 19(5): 27-34.

Neumann, A. and Hirschhausen, Ch. Less Long-Term Gas to Europe? A Quantitative Analysis of European Long-Term Gas Supply Contracts. Zeitschrift fur Energiewirtschaft. 2004, 28(3): 175-182.

OAO Gazprom v. Republic of Lithuania. Final Award. 31 July, 2012. Arbitration No.: v. (125/2011) [interactive]. [accessed on 03-06-2013]. <http://arbitrations.ru/files/ articles/uploaded/Gazprom_v_Lithuania_ Final_Award_SCC.pdf $>$.

Opinion of Advocate General Jacobs in Case C-7/97 Oscar Bronner GmbH \& Co. $K G$ v. Mediaprint Zeitungs- und Zeitschriftenverlag GmbH \& Co. KG and Others [1998] ECR I-07791.

Putting a Price on Energy: International Pricing Mechanisms for Oil and Gas. ECT secretariat, 2007. 
Regulation (EU) No 713/2009 of the European Parliament and of the Council establishing an Agency for the Cooperation of Energy Regulators. [2009] OJ L 211/1.

Regulation (EU) No 714/2009 of the European Parliament and Council Regulation on conditions for access to the network for cross-border exchanges in electricity repealing Regulation (EC) No 1228/2003. [2009] OJ L 211/15.

Regulation (EU) No 715/2009 of the European Parliament and of the Council on conditions for access to the natural gas transmission networks and repealing Regulation (EC) No 1775/2005. [2009] OJ L 211/36.

Regulation (EU) No 994/2010 of the European Parliament and of the Council concerning measures to safeguard security of gas supply and repealing Council Directive 2004/67/ EC. [2010] OJ L 295/1.

REN/Turbogas (Notice pursuant to Article 19(3) of Regulation 17) [1996] OJ C118/7.
RWE Gas Closure (Case COMP/39.402) Commission Decision of 18 March, 2009. [2009] OJ C 133/8.

Smith, E.; Dzienkowski, J. et al. International Petroleum Transactions. Rocky Mountain Mineral Law Foundation, 2010.

Stern, J. Is There a Rationale for the Continuing Link to Oil Product Prices in Continental European Long Term Contracts? OIES. 6. 2007.

Talus, K. Long-term Natural Gas Contracts and Antitrust Law in the European Union and the United States. Journal of World Energy Law and Business. 2011, (4/13): 260-315.

Tidikis, R. Socialiniu moksly tyrimu metodologija. [Methodology of Social Sciences Research]. Lietuvos Teisès Universitetas, 2003.

XIIIth Report on Competition Policy (1983).

Wish, R. Competition Law. 6 edition. Oxford, 2008 .

\section{ILGALAIKIŲ ENERGIJOS TIEKIMO SUTARČIŲ PERSPEKTYVA EUROPOS SAJUNGOS KONKURENCIJOS TEISĖS KONTEKSTE}

\section{Laura Rimšaite}

Mykolo Romerio universitetas, Lietuva

Santrauka. Šiame straipsnyje nagrinëjamas energetikos sektoriuje vyraujančiu ilgalaikiu tiekimo sutarčiu santykis su trečiuju šaliu prieigos teise. Ilgalaikès energijos tiekimo sutartys kelia nemažai problemu, siekiant sukurti rinkos konkurencinguma, padidinti energijos ištekliu diversifikavima, kadangi pagal sutarti paprastai yra isipareigojama ilgam laikotarpiui tiekti atitinkamą kieki energijos ištekliu, už kuri yra suderama mokèti tam tikrą kainą, šiose sutartyse numatomi energijos tiekimo kiekiai nèra peržiürimi pagal rinkos tendencijas. Esmine problema kyla dèl to, kad vyraujant ilgalaikèms tiekimo sutartims, naujiems ükio subjektams tampa sudetinga patekti $i$ rinka, o perdavimo tinklu savininkai neretai piktnaudžiauja direktyvose numatyta galimybe atsisakyti suteikti prieigos teise, motyvuodami turimomis ilgalaikio tiekimo sutartimis su imk arba mokèk išlyga. Konkurencijos teises aspektu kyla klausimu ir dèl kitu ilgalaikèse tiekimo sutartyse numatomu apribojimu, rinkos pasidalijimo mechanizmu bei pajëgumu rezervacijų. Kartu reikia pažymèti, kad ilgalaikès energijos ištekliu tiekimo sutartys yra energijos tiekimo saugumo bei stabilumo užtikrinimo 
garantas. Straipsnyje analizuojamas minètu sutarčiu prieštaringumas bei ju tolesne perspektyva konkurencingos Europos Sajungos energetikos rinkos sukürimo kontekste.

Trečiuju šaliu prieigos teise prie tinklu, kuri numatyta dujų bei elektros direktyvose, sukuria prielaidas konkurencingos vidaus rinkos energetikos sektoriuje sukürimui, tačiau kartu siose direktyvose yra numatytos leidžiančios nukrypti nuostatos, t. y. nepakankami tinklu pajegumai, su viešuju paslangu teikimu susijusios pajeggumu rezervacijos, imk arba mokèk išlygos taikymas ilgalaikese sutartyse, kurios nesilaikymas suponuotu didelius finansinius nuostolius perdavimo tinklu bendrovei. Tokiomis teisemis neretai piktnaudžiauja perdavimo tinklu bendroves.

Ilgalaikès energijos tiekimo sutartys yra svarbus veiksnys, siekiant užtikrinti energetikos sektoriuje patiriamu dideliu pradiniu investiciju, skirtu infrastruktūros įrengimui, atsiperkamuma. Tai ypač aktualu nauju dujotiekiu, naftos ar branduoliniu energetikos infrastruktüros projektu finansavimo stabilumui užtikrinti. Svarbu, kad šiomis sutartimis nebütu sukuriamos išskirtinai palankesnès salygos minètiems subjektams, todèl reikètu vertinti bütinaji investiciju atsiperkamumo laikotarpi, kuriam vis dèlto galètu büti užtikrinama patirtu investiciju grąża numatomomis ilgalaikemis sutartimis.

Reikšminiai žodžiai: ilgalaikès energijos tiekimo sutartys, piktnaudžiavimas dominuojančia padètimi, imk arba mokèk išlyga, trečiuju šaliu prieigos teisè, Trečiasis energetikos paketas, perdavimo tinklai, Europos Sajungos energetikos vidaus rinka.

Laura Rimšaitė, Mykolo Romerio universiteto Teisès fakulteto Verslo teisès katedros doktorantè. Mokslinių tyrimų kryptys: energetikos teisè, konkurencijos teisè, Europos Sajungos teisè.

Laura Rimšaitė, Mykolas Romeris University, Faculty of Law, Department of Business Law, doctoral student. Research interests: Energy Law, Competition Law, European Union Law. 